\title{
Additive Manufacturing and Business Models: Current Knowledge and Missing Perspectives
}

\author{
Christina Öberg, Tawfiq Shams, and Nader Asnafi
}

\author{
"With 3D printing, complexity is free. The printer") \\ doesn't care if it makes the most rudimentary shape or \\ the most complex shape, and this is completely turning \\ design and manufacturing on its head as we know it.
}

Avi Reichental

CEO, 3D Systems

\begin{abstract}
Additive manufacturing, that is $3 \mathrm{D}$ printing technology, may change the way companies operate their businesses. This article adopts a business model perspective to create an understanding of what we know about these changes. It summarizes current knowledge on additive manufacturing within management and business research, and it discusses future research directions in relation to business models for additive manufacturing. Using the scientific database Web of Science, 116 journal articles were identified. The literature review reveals that most research concerns manufacturing optimization. A more holistic view of the changes that additive manufacturing may bring about for firms is needed, as is more research on changed value propositions, and customer/sales-related issues. The article contributes to previous research by systematically summarizing additive manufacturing research in the business and management literature, and by highlighting areas for further investigation related to the business models of individual firms.
\end{abstract}

\section{Introduction}

In recent years, interest has risen in additive manufacturing, that is, layer-based 3D printing of goods (Conner et al., 2014; Go \& Hart, 2016). Although concerns are still placed on the challenges of getting the technology to work (Gardan, 2016), several industry actors have started to explore the business potential of additive manufacturing. Research largely remains focused on the technological advancement, although voices have recently been raised about how additive manufacturing research needs to be integrated with industry (Simpson et al., 2017), and thereby affecting business practices. In short, additive manufacturing is expected to change the ways in which business is run (Brennan et al., 2015; MacCarthy et al., 2016).

This article focuses on the meaning of additive manufacturing for individuals firms by adopting a business model perspective (Osterwalder \& Pigneur, 2010; Zott et al., 2011) on additive manufacturing. Business models refer to conceptual descriptions of a company and its business logic (Osterwalder et al., 2005; Zott et al., 2011), that is, how the company is organized and earns its income. Business modelling describes change processes related to how business is pursued (Zott \& Amit, 2010). For additive manufacturing, such changes would follow from the prospective for local manufacturing (e.g., Rogers et al., 2016), but also from completely new designs and materials (Sharma et al., 2017), and companies may try to reposition themselves along the supply chain as their current positions are challenged by local manufacturing and home-based production, for instance (Shams \& Öberg, 2017), in turn affecting the business models.

This article addresses whether companies' business models and changes to them are considered in the present literature on additive manufacturing, and how changes to individual companies' operations can be understood from present research. The article presents a literature review on additive manufacturing with the underlying question of whether and how the research indicates new business models of companies, the transformation of current business models, or the development of completely new ones. The purpose of the 


\section{Additive Manufacturing and Business Models: Current Knowledge and Missing Perspectives Christina Öberg, Tawfiq Shams, and Nader Asnafi}

article is to summarize current knowledge on additive manufacturing within management and business research, and to discuss future research directions in relation to business models for additive manufacturing.

The article contributes to previous research by examining how the emergence of additive manufacturing affects existing business models. It further points out research gaps in the intersection of additive manufacturing and business models. The contributions are important due to the emerging practical interest in additive manufacturing (Simpson et al., 2017) and because the literature specifically focusing on business models and their changes related to additive manufacturing has not previously been systematically summarized and analyzed.

The rest of the article is structured as follows. After this introduction, the theoretical building block of business models is presented, followed by the research design. Findings from the literature review are described and analyzed by looking into business model traces in the literature. The article ends with conclusions and a description of a future research agenda on additive manufacturing linked to business models.

\section{Business Models}

Business models describe a company's business logic: what it does, how it is organized, how it earns its income, and how it reaches those resources needed (Osterwalder \& Pigneur, 2010). They thereby adopt a holistic perspective on the company's business (Bolton \& Hannon, 2016) and link various activities together (Zott \& Amit, 2010) at the centre of what is offered to customers (Margretta, 2002; Teece, 2010). In the general description of business models, one key aspect is the border between activities of the company and those of external parties. Research has here referred to how business models may be open or include border-spanning activities (Vanhaverbeke \& Chesbrough, 2014), thus emphasizing the business model's connection to supply-chain decisions (Lambert et al., 1998; Nordin et al., 2010) in how the business model includes make-or-buy decisions related to core and strategic competences of the firm.

The literature provides several ways to describe business models, often reflected as canvas and non-canvas models. The canvas models refer to illustrative descriptions of a company's different processes (such as resource provision, value creation, and customer offering, as in Osterwalder et al., 2005), whereas the non-canvas models refer to textual descriptions of, for instance, activities (such as the description of content, structure, and governance of activities, as in Zott \& Amit, 2010). The business model canvas (Osterwalder \& Pigneur, 2010) describes key resources, activities, and partners on the providing side; the value proposition (the offering); customer relationships, segments, and channels on the sales side; along with revenue streams and cost structures. Key resources, activities, and partners describe what is needed to produce the company's services or products, and what part of these are made by the company or other companies. The value proposition reflects how the company puts forth its products or services to customers that are then to decide their value. It includes the product, price, extended product, etc., and is what creates the competitive edge of the company's offering. How the customers are reached is understood through descriptions of channels (such as through independent retailers, the Internet, etc.), whereas segments describe what portion of the market the company aims to reach. Customer relationships, lastly, reflect the relational or transactional characteristic of exchanges along with how resale is created. Cost structures define the types of costs (fixed, variable, etc.) that the company's operations create, whereas revenue streams reflect structures of payments and financial deals with customers.

Business modelling puts focus on the development of new business models or changes to current ones, resulting from opportunities in the market as well as challenges manifested in awareness of contextual change (Johnson et al., 2008). In the case of additive manufacturing, new technologies may constitute challenges as well as opportunities for companies linked to rapid prototyping, rapid tooling, direct manufacturing, and home fabrication (Rayna \& Striukova, 2016), for instance, which would affect and require changes to the company's business model.

As a means to analyze previous additive manufacturing literature in the business and management research, this article juxtaposes the ideas of Osterwalder and Pigneur (2010) with those of Zott and Amit (2010), so as to capture business models (Osterwalder \& Pigneur, 2010) and changes to them (Zott \& Amit, 2010). Figure 1 outlines this framework. Osterwalder and Pigneur's (2010) framework consists of the following: key resources, key partners, key activities, the value proposition, customer relationships, customer segments, channels, revenue streams, and cost structures. Zott and Amit's (2010) description of content, structure, and governance refers to what activities are pursued (content), how they are linked (structure), and who performs the activities (governance), so as to capture their changes. 


\section{Additive Manufacturing and Business Models: Current Knowledge and Missing \\ Perspectives Christina Öberg, Tawfiq Shams, and Nader Asnafi}
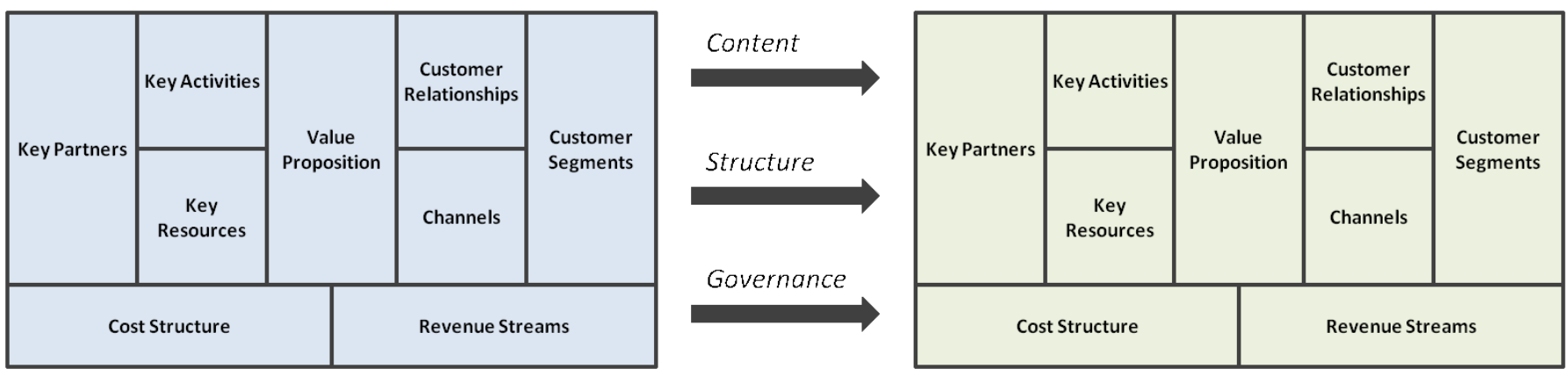

Figure 1. Analytical framework

\section{Research Design}

The article is based on a systematic literature review (cf. Tranfield et al., 2003) conducted as two separate searches so as to capture business models and business model changes in the additive manufacturing and 3D printing literature. The first search provided a very limited number of articles, therefore a second search focused more broadly on additive manufacturing and 3D printing in the business, management, and operational management literature to see whether any traces of business model parts (Osterwalder \& Pigneur, 2010) were described in that literature. Both searches used the academic database Web of Science. The literature reviews were delimited to journal articles (thus excluding conference proceedings, etc.). The reason for using the search terms "additive manufacturing" and "3D printing", respectively, was how an initial search only including additive manufacturing failed to capture some of the predefined relevant articles connecting related methods to business models.

The first search, which focused on "additive manufacturing" or "3D printing" in combinations with "business model" or "business logic" resulted in a total of seven journal articles for the years 2014-2017 (starting date set by occurrence in the database, end date defined to capture entire years):

1. Bogers, Hadar, and Bilberg (2016)

2. Flammini, Arcese, Lucchetti, and Mortara (2017)

3. Holzmann, Breitenecker, Soomro, and Schwarz (2017)

4. Kurman (2014)

5. Laplume, Anzalone, and Pearce (2016a)

6. Pisano, Pironti, and Rieple (2015)

7. Rayna and Striukova (2016)

Among these articles, the one by Flammini and co-authors (2017) does not describe additive manufacturing beyond exemplifying it as one of several technologies, leaving only six articles for further inclusion.
Based on the limited number of articles resulting from the initial search, the second search was conducted, this time focusing on the description of any of the parts of the business model canvas (Osterwalder \& Pigneur, 2010) or changes thereto as means to code articles in the business and management area. Rather than searching for each of these terms and variations thereof, this second search focused on business research on additive manufacturing and 3D printing and then analyzed the articles through the business model canvas. The search focused on the following research areas: operations research management science, management, and business (research areas defined by the database).

The second search resulted in 82 journal articles referring to additive manufacturing and 66 journal articles describing 3D printing. Among these, 34 journal articles overlapped, leading to 114 unique publications. In the analysis, these journal articles were combined with the result of the initial search meaning that a total of 116 journal articles were analyzed (thus representing an overlap of four articles between the searches). To verify the search result, complementary searches were performed in the databases Scopus and Business Source Premier. Although these searches captured additional publications, the publications were excluded based on the low ranking of the journals or were news items, and similar (and not journal articles).

The 116 articles were analyzed to figure out what assumptions were made about additive manufacturing/3D printing in relation to companies and their management, how the business/management scholars linked to the technological side of additive manufacturing/3D printing, and whether and how the scholars described a process of change, current business models (or parts of business models), or completely new actors and business models entering into a business sector, thus implying a remodelling also on the industry level. More specifically, the journal articles were classified into whether they concerned key resources, key partners, 


\section{Additive Manufacturing and Business Models: Current Knowledge and Missing Perspectives Christina Öberg, Tawfiq Shams, and Nader Asnafi}

key activities, the value proposition, customer relationships, customer segments, channels, revenue streams, or cost structures. The changes to these were then discussed in terms of changes to content, structures and governance mechanisms as extracted from the different parts of the business models (Zott \& Amit, 2010). Appendices 1,2 and 3 present the articles reviewed and their classifications and content specifications.

\section{Findings}

\section{Frequencies}

Figure 2 illustrates the frequencies of journal articles per search term (additive manufacturing, 3D printing, or both combined) and by year. As indicated by the figure, there has been a steep rise in the number of journal articles on additive manufacturing and 3D printing during the past few years. Although the data includes few articles published before 2014, it nonetheless suggests that the frequent use of $3 \mathrm{D}$ printing as a keyword is a recent trend.

In terms of the types of journals, most of them have a strong technology/innovation or operations management orientation, with Journal of Manufacturing Systems (17 publications), Journal of Manufacturing Technology Management (14 publications), International Journal of Production Research (10 publications), and Technological Forecasting and Social Change (10 publications) dominating. The type of journals is partly reflected in the key research areas, which focus on the way a company's offering is produced (key resources and key activities) rather than the value proposition or sales/customer side of the business model, as discussed below.

\section{Business models in additive manufacturing}

As Table 1 reveals, most of the journal articles concern the providing side (key partners, resources, and activities) of the business models (77 journal articles in total), with the main emphasis on key activities (42 articles), seconded by key resources (29 articles). These articles concern such issues as how manufacturing is or should be organized with additive manufacturing, the comparison between traditional and additive manufacturing (Achillas et al., 2015), or descriptions of a specific manufacturing process (Zhao et al., 2017). Additionally, several of these articles only refer to additive manufacturing as one of several technologies affecting the future development of producing firms (Hoover \& Lee, 2015; Mortara \& Parisot, 2016; Pisano et al., 2015).

As for changes, it is mainly the key activities that are expected to change due to the introduction of additive manufacturing. Mavri (2015), for instance, describes how the production chain changes due to additive manufacturing. Ben-Ner and Siemsen (2017) and Laplume, Petersen, and Pearce (2016b) include the change of supply chains in this regard, describing the shift from global to local, and from long to short supply chains. While not being very specific about the changes of "who does what", articles by Ben-Ner and Siemsen's (2017) and Laplume and colleagues (2016b) indicate a change of governance (cf. Zott \& Amit, 2010), whereas Mavri (2015) and most other articles focusing on changes to production concern the change of content (activities pursued; cf. Zott \& Amit, 2010). This also means that additive manufacturing would foremost be seen changing internal processes of the firm, also indicated by the quite limited number of articles (six) focusing on key partners. The articles concerning key partners mainly

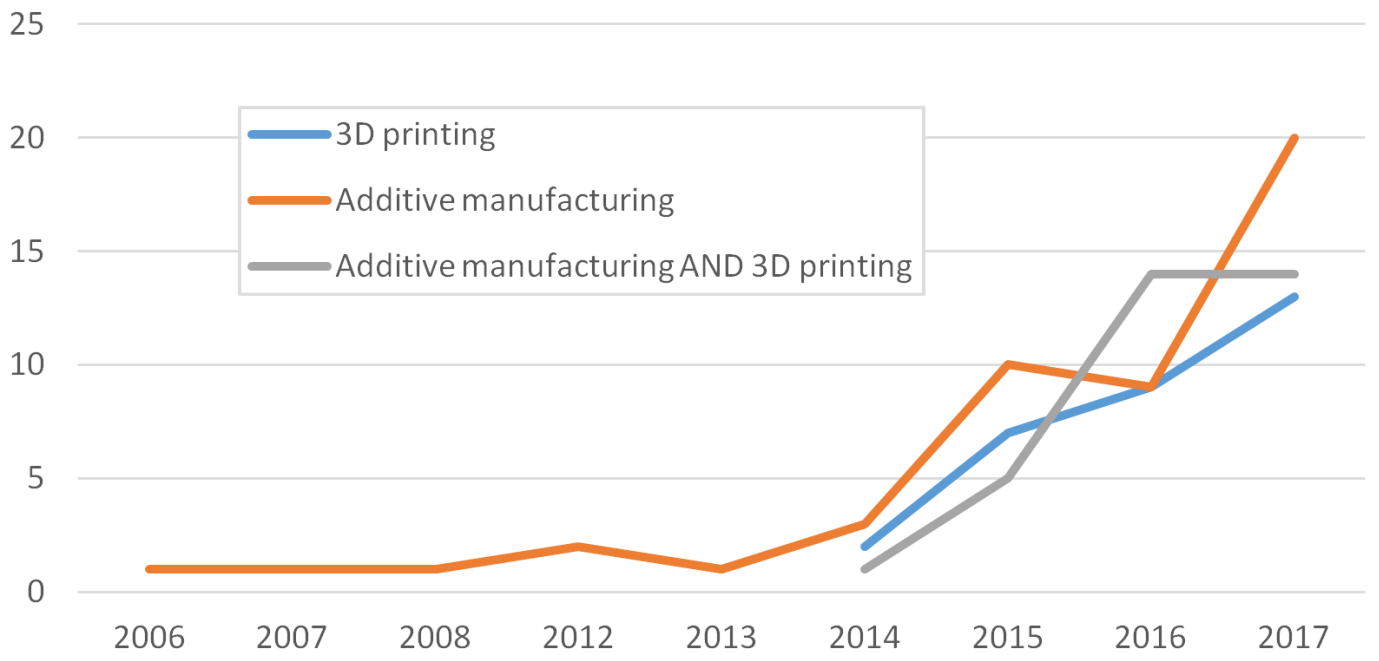

Figure 2. Frequency of results for each search term by year 


\section{Additive Manufacturing and Business Models: Current Knowledge and Missing \\ Perspectives Christina Öberg, Tawfiq Shams, and Nader Asnafi}

Table 1. Key themes by year

\begin{tabular}{|c|c|c|c|c|c|c|c|c|c|c|}
\hline Theme & 2006 & 2007 & 2008 & 2012 & 2013 & 2014 & 2015 & 2016 & 2017 & Total \\
\hline Key partners & & & & & & & 1 & 1 & 4 & 6 \\
\hline Key activities & 1 & & 1 & & & 4 & 9 & 13 & 14 & 42 \\
\hline Key resources & & 1 & & 1 & & 2 & 6 & 7 & 12 & 29 \\
\hline Value proposition & & & & 1 & 1 & & 1 & 4 & 6 & 13 \\
\hline Customer relationships & & & & & & 1 & 2 & & & 3 \\
\hline Cost structure & & & & & & & & 2 & 2 & 4 \\
\hline Revenue stream & & & & & & & 1 & & & 1 \\
\hline Policy/societal level & & & & & & & 1 & & 3 & 4 \\
\hline Not in focus & & & & 1 & & & 1 & 6 & 6 & 14 \\
\hline Total & 1 & 1 & 1 & 3 & 1 & 7 & 22 & 33 & 47 & 116 \\
\hline
\end{tabular}

describe platforms or communities for design, examine technology transfers from universities, or emphasize the difficulties for small firms to adopt the technology (Birtchnell et al., 2017; Flath et al., 2017; Samford et al., 2017; West \& Kuk, 2016). The limited attention paid to key partners implies that additive manufacturing would not require any major changes to core competences of firms or the companies would be equipped to change their current competences to fit with future needs. Related to this, is an acknowledgement of how additive manufacturing could expect to create disruption for certain companies along the supply chain (Mohr \& Khan, 2015).

As for key resources, the discussion in the literature focuses on such issues as intellectual property rights (Gardan \& Schneider, 2015; Kurman, 2014; Steenhuis \& Pretorius, 2017), manufacturing issues and printer choices (Dwivedi et al., 2018; Elango et al., 2016; Paul \& Anand, 2015), skills and (financial) support systems, and how new structures may be produced using additive manufacturing (Gardan \& Schneider, 2015; Vongbunyong \& Kara, 2017; Zhao et al., 2017). While partly concerning changes to resources (such as new skills or changes to intellectual property rules), most articles on key resources describe quite a static view, also not indicating any changes to content, structures, or governance (Zott \& Amit, 2010).

As for the offering, 13 journal articles concern value propositions (cf. Osterwalder \& Pigneur, 2010). These include the type of products produced through additive manufacturing: rapid prototyping and innovations, for instance (Berman, 2012; Maric et al., 2016; Rayna \& Striukova, 2016; Salles \& Gyi, 2013). Rayna and Striukova (2016) make an overview of various offerings and the incremental or radical change they describe, and Laplume and co-authors (2016a) illustrate how small firms use 3D technology in their offerings. Others link additive manufacturing to business performance or business impact more generally (Niaki \& Nonino, 2017; Rylands et al., 2016), or describe how incumbent firms would react to the entrance of 3D technology or 3D-printer firms (Hartl \& Kort, 2017; Kietzmann et al., 2015). The articles concerning the value propositions broadly defined partly point at changed governance (Zott \& Amit, 2010) as new players may enter, but mostly indicate an increased number of practices and thereby offerings enabled through additive manufacturing. 


\section{Additive Manufacturing and Business Models: Current Knowledge and Missing Perspectives Christina Öberg, Tawfiq Shams, and Nader Asnafi}

As for the sales side, only three journal articles could be seen to concern customer-related issues, then focusing on customer relationships or changes to them. Rayna, Striukova, and Darlington (2015) discuss co-creation with customers in relation to 3D printing. Christopher and Ryals (2014) introduce the idea of demand chains to emphasize how additive manufacturing means customization and how ideas are pulled by customers rather than created by manufacturers and pushed onto customers. Appleyard (2015), lastly, reflects on piracy music as a means to understand 3D as a process owned by consumers. Thus, the limited literature on the sales side indicates how customers increase their influence and activity on what is produced, thus implying a change in governance of ideas (Zott \& Amit, 2010), or "who does what".

The cost structure is discussed in four articles focusing on the analysis of total costs of production or a change in the cost structure with printers being expensive, while the cost of producing low series is less so (Baumers et al., 2016; Baumers et al., 2017; Manogharan et al., 2016; Tsai, 2017). As for revenue streams, Weller, Kleer, and Piller (2015) discuss revenues related to entry barriers and point at how additive manufacturing may lower entrance barriers, thereby impacting competition and revenues.

In addition to those articles that could be linked to any part of the business model, there are a few journal articles focusing on the societal and policy level, along with a total of 14 articles having 3D printing as one of several empirical examples, while not giving the technology or its business impact any focus.

\section{Summary of results}

To summarize the findings, most journal articles thus concern the providing side of the business model, often with an internal manufacturing focus. Optimization is discussed either including changes to activities or meaning that 3D printing is a technology used in processes similar to those of traditional manufacturing. Little suggests knowing about changes to structures (cf. Zott \& Amit, 2010), whereas key activities are linked to potential activity changes, and key resources are linked more to static descriptions. The discussion on key partners is limited, where supply chain discussions are quite general while not describing partnerships. Notably, the literature seems to imply that the companies in their internal processes are expected to adjust their core competences to new production methods, rather than link these to partnerships. Value propositions de- scribe various offerings enabled through additive manufacturing, focusing on innovations and prototyping mostly, whereas the literature on the sales side/customer-related issues concerns the increased involvement of customers, implying a possible shift in power (cf. Öberg, 2018) to the customers' advantage. Discussions on change in business models or their parts focus on some changes to content (activities) related to production, and some few examples of changes in governance (who does what) in supply-chain structures and the shift to customers' activities, whereas the structures (the links among activities), and thereby the holistic business model influence of additive manufacturing does not seem to be described in previous research. Early articles seemed to be more prescriptive about what would happen, while more recent ones are more questioning to $3 \mathrm{D}$ printing/additive manufacturing.

\section{Conclusions}

This article summarizes current knowledge on additive manufacturing within management and business research, which leads us now to a discussion of future research directions in relation to business models for additive manufacturing. The literature review indicates a continuous focus on production issues also in the business and management literature. There is an indicated shift from positive connotations to increased questioning of the entrance and meaning of additive manufacturing in the production systems of tomorrow. There is also, when describing how business may change, the tendency to relate to parallel developments in business: the co-production and increased fuzziness between producers and consumers as crowds and communities affect design and production procedures (Ebner et al., 2009; Gulati et al., 2012; von Krogh et al., 2003) that would not be the direct consequence of additive manufacturing.

In terms of business models, what is rarely considered are changes in key partners, entirely new type of offerings, or revenue streams. What is also not considered is how individual companies, given their supply chain position, change or need to change their positions but also competences to meet those challenges and opportunities that additive manufacturing may bring about (Shams \& Öberg, 2017). Changes to how various activities are linked are seldom described, which could imply that additive manufacturing is viewed from the lens of traditional manufacturing. And, empirical data beyond measurement in calculations of internal company optimization of manufacturing is rare. 


\section{Additive Manufacturing and Business Models: Current Knowledge and Missing Perspectives Christina Öberg, Tawfiq Shams, and Nader Asnafi}

\begin{abstract}
A research agenda for additive manufacturing and business models

Studies on additive manufacturing and its impact on business models are thus scarce, and there is a need to further explore the area and its many different aspects. Specifically, more empirical work is needed, moving knowledge away from scenarios and into how 3D printing in fact affects current businesses on the company level. The following research streams are suggested:
\end{abstract}

- Research on value propositions and customer-related issues. This would include how offerings are presented, decisions on channels and segments, and their consequences for firm performance. The holistic view including all parts of the business model and how various business models affect the performance of the firm in relation to additive manufacturing would also be important to study, as would the focus on structures (links among activities, cf. Zott \& Amit, 2010).

- Research focusing on how individual firms based on their present roles as manufacturers/suppliers, logistics providers, and business customers would change or need to change their roles so as to fit with additive manufacturing. Such research would include the study of various companies as units of analysis and how additive manufacturing would lead to new business opportunities, or constrain current ones. Depending on the company's position in the supply chain, the vulnerability to additive manufacturing would differ, and the studies could compare companies based on their various supply-chain positions, while thus focusing on the company level.

- Research on the effects of parts, tooling, and prototyping. This would include how companies at various supply chain position would be affected by, take on, and also potentially try to move into more lucrative positions as, for instance, part manufacturing would be insourced by other companies. Comparisons could here be made among companies at each position for the effects of parts, tooling, and prototyping, respectively.

- Research on what competences are needed as companies adapt to additive manufacturing and depending on the company's current role. Competences would not only include those of additive manufacturing, but also competences on how offerings could be created, and they may well mean that a company manages to keep its position based on specific competences, while it would otherwise be challenged by the additive manufacturing. Competences should ideally be studied over time to see how requirements of them change, and how companies develop and adjust them. The role of key partners and thereby structures and governance would be important to study in relation to competences.

- Research into how payment models should be designed to minimize financial risks, while also taking into account the high investments of additive manufacturing. The payment systems and price strategies of today traditionally focus on how a customer pays the supplier for products delivered. In multiple-party systems, and if competences become a key concern, the way and for what payments are made could expect to change and create new and more creative business models.

- Research taking a deeper look into customer interaction from the perspective of home-based production. While it is important to contextualize any development, it is also important to study the customer interaction as an isolated activity (that is, not in conjunction with, for instance, community trends) so as to understand how roles and powers are changed for parts, tooling, and prototyping, respectively.

- Research into additive manufacturing/3D printing using different materials. Most studies concern plastic materials, and it would be important to compare how various materials change the business models of companies in similar or different ways. This would include comparing plastics with metal printing, for instance, in how they would cause changes to business models of companies.

\section{Managerial implications}

Related to the findings from this article and also the research gaps indicated above, it would be important for any manager introducing additive manufacturing, or challenged by competitors doing so, to grasp how the interaction with customers could expect to change, what additive manufacturing means for cost structures - and thereby risk - but also what competences would be required to successfully operate the new technology. The literature indicates some changes to manufacturing as additive manufacturing is introduced, but in addition to these, it would be important to carefully analyze what activities may be excluded, how this affects the current business and connections to key partners, along with the business performance of the company. Hence, there are several issues to consider, where the present literature gives a good overview of effects on production, but less often links this to the entirety of the company. Through adopting a holistic 


\section{Additive Manufacturing and Business Models: Current Knowledge and Missing Perspectives Christina Öberg, Tawfiq Shams, and Nader Asnafi}

business model perspective on the introduction of additive manufacturing and its consequences, it is easier to also grasp the coordination of activities (the structures, Zott \& Amit, 2010). Furthermore, specific attention should be directed at how additive manufacturing may provide opportunities in terms of new offerings, customer involvement, and customization, along with production-to-order, and how these affect the business model from a provision, offering, sales, and cost/revenue side.

\section{About the Authors}

Christina Öberg is Professor/Chair in Marketing at Örebro University in Sweden, and she is also associated with The Ratio Institute, the University of Exeter, and Leeds University. She has a background from Linköping University and Lund University and has also been a visiting scholar at Stanford University, the University of Bath, and Manchester University. Her research interests concern mergers and acquisitions, customer relationships, innovations, and new ways to pursue business including the sharing economy and effects of additive manufacturing. She has previously published in such journals as the Journal of Business Research, Industrial Marketing Management, International Marketing Review, the European Journal of Marketing, and Production Planning \& Control.

Tawfiq Shams is a PhD candidate in Business Model Innovation (Additive Manufacturing) at Örebro University in Sweden. He works in parallel as a business consultant in the area of additive manufacturing, and his doctoral thesis deals with business model changes as the result of additive manufacturing. He holds a Master's degree from the University of Gothenburg, Sweden, and Copenhagen Business School, Denmark.

Nader Asnafi is a Professor in Mechanical Engineering at Örebro University in Sweden. He has an industrial background including many years at leading positions within Volvo, Uddeholm, Sapa, and Esselte Dymo. His research interests include industrial effectiveness, product planning and realization, materials, product and production development, and manufacturing engineering and systems.

\section{References}

Aboutaleb, A. M., Bian, L. K., Elwany, A., Shamsaei, N., Thompson, S. M., \& Tapia, G. 2017. Accelerated Process Optimization for LaserBased Additive Manufacturing by Leveraging Similar Prior Studies. IISE Transactions, 49(1): 31-44.

http://doi.org/10.1080/0740817x.2016.1189629

Achillas, C., Aidonis, D., Iakovou, E., Thymianidis, M., \& Tzetzis, D. 2015. A Methodological Framework for the Inclusion of Modern Additive Manufacturing into the Production Portfolio of a Focused Factory. Journal of Manufacturing Systems, 37(1): 328-339. http://doi.org/10.1016/j.jmsy.2014.07.014

Achillas, C., Tzetzis, D., \& Raimondo, M. O. 2017. Alternative Production Strategies Based on the Comparison of Additive and Traditional Manufacturing Technologies. International Journal of Production Research, 55(12): 3497-3509. http://doi.org/10.1080/00207543.2017.1282645

Ali, M. N., \& Rehman, I. U. 2015. Auxetic Polyurethane Stents and Stent-Grafts for the Palliative Treatment of Squamous Cell Carcinomas of the Proximal and Mid Oesophagus: A Novel Fabrication Route. Journal of Manufacturing Systems, 37: 375-395. http://doi.org/10.1016/j.jmsy.2014.07.009

Ambriz, S., Coronel, J., Zinniel, B., Schloesser, R., Kim, C. Y., Perez, M., Espalin, D., \& Wicker, R. B. 2017. Material Handling and Registration for an Additive Manufacturing-Based Hybrid System. Journal of Manufacturing Systems, 45: 17-27. http://doi.org/10.1016/j.jmsy.2017.07.003

Appleyard, M. 2015. Corporate Responses to Online Music Piracy: Strategic Lessons for the Challenge of Additive Manufacturing. Business Horizons, 58(1): 69-76. http://doi.org/10.1016/j.bushor.2014.09.007

Attaran, M. 2017. The Rise of 3D Printing: The Advantages of Additive Manufacturing over Traditional Manufacturing. Business Horizons, 60(5): 677-688.

http://doi.org/10.1016/j.bushor.2017.05.011

Bai, X., Liu, Y., Wang, G. B., \& Wen, C. C. 2017. The Pattern of Technological Accumulation: The Comparative Advantage and Relative Impact of 3D Printing Technology. Journal of Manufacturing Technology Management, 28(1): 39-55. http://doi.org/10.1108/jmtm-10-2016-0136

Bastani, K., Rao, P. K., \& Kong, Z. Y. 2016. An Online Sparse Estimation-Based Classification Approach for Real-Time Monitoring in Advanced Manufacturing Processes from Heterogeneous Sensor Data. IIE Transactions, 48(7): 579-598. http://doi.org/10.1080/0740817x.2015.1122254

Baumers, M., Beltrametti, L., Gasparre, A., \& Hague, R. 2017. Informing Additive Manufacturing Technology Adoption: Total Cost and the Impact of Capacity Utilisation. International Journal of Production Research, 55(23): 6957-6970. http://doi.org/10.1080/00207543.2017.1334978

Baumers, M., Dickens, P., Tuck, C., \& Hague, R. 2016. The Cost of Additive Manufacturing: Machine Productivity, Economies of Scale and Technology-Push. Technological Forecasting and Social Change, 102: 193-201.

http://doi.org/10.1016/j.techfore.2015.02.015 


\section{Additive Manufacturing and Business Models: Current Knowledge and Missing Perspectives Christina Öberg, Tawfiq Shams, and Nader Asnafi}

Ben-Ner, A., \& Siemsen, E. 2017. Decentralization and Localization of Production: The Organizational and Economic Consequences of Additive Manufacturing (3D Printing). California Management Review, 59(2): 5-23.

http://doi.org/10.1177/0008125617695284

Berman, B. 2012. 3-D Printing: The New Industrial Revolution. Business Horizons, 55(2): 155-162. http://doi.org/10.1016/j.bushor.2011.11.003

Bingham, G. A., Hague, R. J. M., Tuck, C. J., Long, A. C., Crookston, J. J., \& Sherburn, M. N. 2007. Rapid Manufactured Textiles. International Journal of Computer Integrated Manufacturing, 20(1): 96-105. http://doi.org/10.1080/09511920600690434

Birtchnell, T., Bohme, T., \& Gorkin, R. 2017. 3D Printing and the Third Mission: The University in the Materialization of Intellectual Capital. Technological Forecasting and Social Change, 123: 240-249.

http://doi.org/10.1016/j.techfore.2016.03.014

Bogers, M., Hadar, R., \& Bilberg, A. 2016. Additive Manufacturing for Consumer-Centric Business Models: Implications for Supply Chains in Consumer Goods Manufacturing. Technological Forecasting and Social Change, 102: 225-239.

http://doi.org/10.1016/j.techfore.2015.07.024

Bolton, R., \& Hannon, M. 2016. Governing Sustainability Transitions Through Business Model Innovation: Towards a Systems Understanding. Research Policy, 45(9): 1731-1742.

Brennan, L., Ferdows, K., Godsell, J., Golini, R., Keegan, R., Kinkel, S., Singh Srai, J., \& Taylor, M. 2015. Manufacturing in The World: Where Next? International Journal of Operations \& Production Management, 35(9): 1253-1274.

Caputo, A., Marzi, G., \& Pellegrini, M. M. 2016. The Internet of Things in Manufacturing Innovation Processes Development and Application of a Conceptual Framework. Business Process Management Journal, 22(2): 383-402.

http://doi.org/10.1108/bpmj-05-2015-0072

Chen, X., \& Xiao, H. 2016. Multirate Forward-Model Disturbance Observer for Feedback Regulation Beyond Nyquist Frequency. Systems \& Control Letters, 94: 181-188. http://doi.org/10.1016/j.sysconle.2016.06.011

Christopher, M., \& Ryals, L. J. 2014. The Supply Chain Becomes the Demand Chain. Journal of Business Logistics, 35(1): 29-35. http://doi.org/10.1111/jbl.12037

Conner, B. P., Manogharan, G. P., Martof, A. N., Rodomsky, L. M., Rodomsky, C. M., Jordan, D. C., \& Limperos, J. W. 2014. Making Sense of 3D Printing: Creating a Map of Additive Manufacturing Products and Services. Additive Manufacturing, 1-4: 64-76.

Deradjat, D., \& Minshall, T. 2017. Implementation of Rapid Manufacturing for Mass Customisation. Journal of Manufacturing Technology Management, 28(1): 95-121.

http://doi.org/10.1108/jmtm-01-2016-0007

Despeisse, M., Baumers, M., Brown, P., Charnley, F., Ford, S. J., Garmulewicz, A., Knowles, S., Minshall, T. H. W., Mortara, L., ReedTsochas, F. P., \& Rowley, J. 2017. Unlocking Value for a Circular Economy Through 3D Printing: A Research Agenda. Technological Forecasting and Social Change, 115: 75-84. http://doi.org/10.1016/j.techfore.2016.09.021
Dotsika, F., \& Watkins, A. 2017. Identifying Potentially Disruptive Trends by Means of Keyword Network Analysis. Technological Forecasting and Social Change, 119: 114-127. http://doi.org/10.1016/j.techfore.2017.03.020

Durach, C. F., Kurpjuweit, S., \& Wagner, S. M. 2017. The Impact of Additive Manufacturing on Supply Chains. International Journal of Physical Distribution \& Logistics Management, 47(10): 954-971. http://doi.org/10.1108/ijpdlm-11-2016-0332

Dwivedi, G., Srivastava, R. K., \& Srivastava, S. K. 2018. A Generalised Fuzzy TOPSIS with Improved Closeness Coefficient. Expert Systems with Applications, 96: 185-195. http://doi.org/10.1016/j.eswa.2017.11.051

Dwivedi, G., Srivastava, S. K., \& Srivastava, R. K. 2017. Analysis of Barriers to Implement Additive Manufacturing Technology in the Indian Automotive Sector. International Journal of Physical Distribution \& Logistics Management, 47(10): 972-991. http://doi.org/10.1108/ijpdlm-07-2017-0222

Ebner, W., Leimeister, J. M., \& Krcmar, H. 2009. Community Engineering for Innovations: The Ideas Competition as a Method to Nurture a Virtual Community for Innovations. $R \& D$ Management, 39(4): 342-256.

Elango, M., Subramanian, N., Marian, R., \& Goh, M. 2016. Distributed Hybrid Multiagent Task Allocation Approach for Dual-Nozzle 3D Printers in Microfactories. International Journal of Production Research, 54(23): 7014-7026. http://doi.org/10.1080/00207543.2016.1171419

Eyers, D. R., \& Potter, A. T. 2015. E-Commerce Channels for Additive Manufacturing: An Exploratory Study. Journal of Manufacturing Technology Management, 26(3): 390-411. http://doi.org/10.1108/jmtm-08-2013-0102

Fawcett, S. E., \& Waller, M. A. 2014. Can We Stay Ahead of the Obsolescence Curve? On Inflection Points, Proactive Preemption, and the Future of Supply Chain Management. Journal of Business Logistics, 35(1): 17-22.

http://doi.org/10.1111/jbl.12041

Featherston, C. R., Ho, J. Y., Brevignon-Dodin, L., \& O'Sullivan, E. 2016. Mediating and Catalysing Innovation: A Framework for Anticipating the Standardisation Needs of Emerging Technologies. Technovation, 48-49: 25-40. http://doi.org/10.1016/j.technovation.2015.11.003

Flammini, S., Arcese, G., Lucchetti, M. C., \& Mortara, L. 2017. Business Model Configuration and Dynamics for Technology Commercialization in Mature Markets. British Food Journal, 119(11): 2340-2358. http://doi.org/10.1108/bfj-03-2017-0125

Flath, C. M., Friesike, S., Wirth, M., \& Thiesse, F. 2017. Copy, Transform, Combine: Exploring the Remix as a Form of Innovation. Journal of Information Technology, 32(4): 306-325. http://doi.org/10.1057/s41265-017-0043-9

Gardan, J. 2016. Additive Manufacturing Technologies: State of the Art and Trends. International Journal of Production Research, 54(10): 3118-3132.

Gardan, N., \& Schneider, A. 2015. Topological Optimization of Internal Patterns and Support in Additive Manufacturing. Journal of Manufacturing Systems, 37: 417-425. http://doi.org/10.1016/j.jmsy.2014.07.003 


\section{Additive Manufacturing and Business Models: Current Knowledge and Missing Perspectives Christina Öberg, Tawfiq Shams, and Nader Asnafi}

Gartner, J., Maresch, D., \& Fink, M. 2015. The Potential of Additive Manufacturing for Technology Entrepreneurship: An Integrative Technology Assessment. Creativity and Innovation Management, 24(4): 585-600.

http://doi.org/10.1111/caim.12132

Giberti, H., Sbaglia, L., \& Urgo, M. 2017. A Path Planning Algorithm For Industrial Processes Under Velocity Constraints with an Application to Additive Manufacturing. Journal of Manufacturing Systems, 43: 160-167.

http://doi.org/10.1016/j.jmsy.2017.03.003

Gibson, I. 2017. The Changing Face of Additive Manufacturing. Journal of Manufacturing Technology Management, 28(1): 10-17. http://doi.org/10.1108/jmtm-12-2016-0182

Go, J., \& Hart, J. 2016. A Framework for Teaching the Fundamentals of Additive Manufacturing and Enabling Rapid Innovation. Additive Manufacturing, 10: 76-87.

Gulati, R., Puranam, P., \& Tushman, M. 2012. Meta-Organization Design: Rethinking Design in Interorganizational and Community Contexts. Strategic Management Journal, 33(6): 571-586.

Han, E. J., \& Sohn, S. Y. 2015. Patent Valuation Based on Text Mining and Survival Analysis. Journal of Technology Transfer, 40(5): 821-839.

http://doi.org/10.1007/s10961-014-9367-6

Hartl, R. F., \& Kort, P. M. 2017. Possible Market Entry of a Firm With an Additive Manufacturing Technology. International Journal of Production Economics, 194: 190-199. http://doi.org/10.1016/j.ijpe.2017.06.013

Hartmann, T., \& Vanpoucke, E. 2017. User Acceptance of Technologies in Their Infancy: The Case of 3D Printing Business Models. Journal of Organizational and End User Computing, 29(2): 1-24.

http://doi.org/10.4018/joeuc.2017040101

Holmstrom, J., Holweg, M., Khajavi, S. H., \& Partanen, J. 2016. The Direct Digital Manufacturing (R)Evolution: Definition of a Research Agenda. Operations Management Research, 9(1-2): 1-10. http://doi.org/10.1007/s12063-016-0106-Z

Holzmann, P., Breitenecker, R. J., Soomro, A. A., \& Schwarz, E. J. 2017. User Entrepreneur Business Models in 3D Printing. Journal of Manufacturing Technology Management, 28(1): 75-94. http://doi.org/10.1108/jmtm-12-2015-0115

Hoover, S., \& Lee, L. 2015. Democratization and Disintermediation Disruptive Technologies and the Future of Making Things. Research-Technology Management, 58(6): 31-36. http://doi.org/10.5437/08956308x5806069

Huang, Q., Zhang, J. Z., Sabbaghi, A., \& Dasgupta, T. 2015. Optimal Offline Compensation of Shape Shrinkage for Three-Dimensional Printing Processes. IIE Transactions, 47(5): 431-441. http://doi.org/10.1080/0740817x.2014.955599

Hull, C. W. 2015. The Birth of 3D Printing IRI Achievement Award Address. Research-Technology Management, 58(6): 25-29. http://doi.org/10.5437/08956308x5806067

Jiang, R., Kleer, R., \& Piller, F. T. 2017. Predicting the Future of Additive Manufacturing: A Delphi Study on Economic and Societal Implications of 3D Printing for 2030. Technological Forecasting and Social Change, 117: 84-97. http://doi.org/10.1016/j.techfore.2017.01.006
Jin, Y., Du, J. K., \& He, Y. 2017. Optimization of Process Planning for Reducing Material Consumption in Additive Manufacturing. Journal of Manufacturing Systems, 44: 65-78. http://doi.org/10.1016/j.jmsy.2017.05.003

Jin, Y., He, Y., \& Du, J. K. 2017. A Novel Path Planning Methodology for Extrusion-Based Additive Manufacturing of Thin-Walled Parts. International Journal of Computer Integrated Manufacturing, 30(12): 1301-1315. http://doi.org/10.1080/0951192x.2017.1307526

Johnson, M. W., Christensen, C. M., \& Kagermann, H. 2008. Reinventing Your Business Model. Harvard Business Review, 86(12): 50-59.

Kannattukunnel, R. S. 2016. Global Patents on 3D Printing: Revelations Based on Vector Autoregression Analysis for Three Decades. International Journal of Innovation and Technology Management, 13(6). http://doi.org/10.1142/s0219877017500043

Kietzmann, J., Pitt, L., \& Berthon, P. 2015. Disruptions, Decisions, and Destinations: Enter the Age of 3D Printing and Additive Manufacturing. Business Horizons, 58(2): 209-215. http://doi.org/10.1016/j.bushor.2014.11.005

Kim, D. B., Denno, P. O., \& Jones, A. T. 2015. A Model-Based Approach to Refine Process Parameters in Smart Manufacturing. Concurrent Engineering-Research and Applications, 23(4): 365-376. http://doi.org/10.1177/1063293x15591038

Knofius, N., van der Heijden, M. C., \& Zijm, W. H. M. 2016. Selecting Parts for Additive Manufacturing in Service Logistics. Journal of Manufacturing Technology Management, 27(7): 915-931. http://doi.org/10.1108/jmtm-02-2016-0025

Kothman, I., \& Faber, N. 2016. How 3D Printing Technology Changes the Rules of the Game Insights from the Construction Sector. Journal of Manufacturing Technology Management, 27(7): 932-943.

http://doi.org/10.1108/jmtm-01-2016-0010

Kurfess, T., \& Cass, W. J. 2014. Rethinking Additive Manufacturing and Intellectual Property Protection. Research-Technology Management, 57(5): 35-42. http://doi.org/10.5437/08956308x5705256

Kurman, M. 2014. Carrots, Not Sticks: Rethinking Enforcement of Intellectual Property Rights for 3D-Printed Manufacturing. 3D Printing and Additive Manufacturing, 1(1): 44-51. http://doi.org/10.1089/3dp.2014.0002

Kyriakou, H., Nickerson, J. V., \& Sabnis, G. 2017. Knowledge Reuse for Customization: Metamodels in an Open Design Community for 3D Printing. MIS Quarterly, 41(1): 315-332.

Lambert, D. M., Cooper, M. C., \& Pagh, J. D. 1998. Supply Chain Management: Implementation Issues and Research Opportunities. The International Journal of Logistics Management, 9(2): 1-19.

Laplume, A., Anzalone, G. C., \& Pearce, J. M. 2016a. Open-Source, SelfReplicating 3-D Printer Factory for Small-Business Manufacturing. International Journal of Advanced Manufacturing Technology, 85(1-4): 633-642.

http://doi.org/10.1007/s00170-015-7970-9

Laplume, A. O., Petersen, B., \& Pearce, J. M. 2016b. Global Value Chains from a 3D Printing Perspective. Journal of International Business Studies, 47(5): 595-609. http://doi.org/10.1057/jibs.2015.47 


\section{Additive Manufacturing and Business Models: Current Knowledge and Missing Perspectives Christina Öberg, Tawfiq Shams, and Nader Asnafi}

Le, V. T., Paris, H., \& Mandil, G. 2017. Process Planning for Combined Additive and Subtractive Manufacturing Technologies in a Remanufacturing Context. Journal of Manufacturing Systems, 44: 243-254.

http://doi.org/10.1016/j.jmsy.2017.06.003

Li, Q., Kucukkoc, I., \& Zhang, D. Z. 2017. Production Planning in Additive Manufacturing and 3D Printing. Computers \& Operations Research, 83: 157-172. http://doi.org/10.1016/j.cor.2017.01.013

Li, Y., Jia, G. Z., Cheng, Y., \& Hu, Y. C. 2017. Additive Manufacturing Technology in Spare Parts Supply Chain: A Comparative Study. International Journal of Production Research, 55(5): 1498-1515. http://doi.org/10.1080/00207543.2016.1231433

Liu, P., Huang, S. H., Mokasdar, A., Zhou, H., \& Hou, L. 2014. The Impact of Additive Manufacturing in the Aircraft Spare Parts Supply Chain: Supply Chain Operation Reference (SCOR) Model Based Analysis. Production Planning \& Control, 25(13-14): 1169-1181.

http://doi.org/10.1080/09537287.2013.808835

Long, Y. G., Pan, J. Y., Zhang, Q. H., \& Hao, Y. J. 2017. 3D Printing Technology and Its Impact on Chinese Manufacturing. International Journal of Production Research, 55(5): 1488-1497. http://doi.org/10.1080/00207543.2017.1280196

MacCarthy, B. L., Blome, C., Olhager, J., Singh Srai, J., \& Zhao, X. 2016. Supply Chain Evolution - Theory, Concepts and Science. International Journal of Operations \& Production Management, 36(12): 1696-1718.

Manogharan, G., Wysk, R. A., \& Harrysson, O. L. A. 2016. Additive Manufacturing-Integrated Hybrid Manufacturing and Subtractive Processes: Economic Model and Analysis. International Journal of Computer Integrated Manufacturing, 29(5): 473-488. http://doi.org/10.1080/0951192x.2015.1067920

Margetta, J. 2002. Why Business Models Matter. Harvard Business Review, 80(5): 86-92.

Maric, J., Rodhain, F., \& Barlette, Y. 2016. Frugal Innovations and 3D Printing: Insights from the Field. Journal of Innovation Economics \& Management, 3: 57-76. http://doi.org/10.3917/jie.021.0057

Mavri, M. 2015. Redesigning a Production Chain Based on 3D Printing Technology. Knowledge and Process Management, 22(3): 141-147.

http://doi.org/10.1002/kpm.1466

Meisel, N. A., Williams, C. B., Ellis, K. P., \& Taylor, D. 2016. Decision Support for Additive Manufacturing Deployment in Remote or Austere Environments. Journal of Manufacturing Technology Management, 27(7): 898-914.

http://doi.org/10.1108/jmtm-06-2015-0040

Mellor, S., Hao, L., \& Zhang, D. 2014. Additive Manufacturing: A Framework for Implementation. International Journal of Production Economics, 149: 194-201. http://doi.org/10.1016/j.ijpe.2013.07.008

Mohr, S., \& Khan, O. 2015. 3D Printing and Its Disruptive Impacts on Supply Chains of the Future. Technology Innovation Management Review, 5(11): 20-25.

http://timreview.ca/article/942

Mortara, L., \& Parisot, N. G. 2016. Through Entrepreneurs' Eyes: The Fab-Spaces Constellation. International Journal of Production Research, 54(23): 7158-7180.

http://doi.org/10.1080/00207543.2016.1198505
Niaki, M. K., \& Nonino, F. 2017. Impact of Additive Manufacturing on Business Competitiveness: A Multiple Case Study. Journal of Manufacturing Technology Management, 28(1): 56-74. http://doi.org/10.1108/jmtm-01-2016-0001

Nordin, F., Öberg, C., Kollberg, B., \& Nord, T. 2010. Building a New Supply Chain Position: An Exploratory Case Study Within the Construction Industry. Construction Management and Economics, 28: $1071-1083$.

Öberg, C. 2018. Additive Manufacturing - Digitally Changing the Global Business Landscape. Paper presented at the 8th Global Innovation and Knowledge Academy (GIKA) Conference, June 25-27, 2018, Valencia, Spain.

Oettmeier, K., \& Hofmann, E. 2016. Impact of Additive Manufacturing Technology Adoption on Supply Chain Management Processes and Components. Journal of Manufacturing Technology Management, 27(7): 944-968.

http://doi.org/10.1108/jmtm-12-2015-0113

Osterwalder, A., \& Pigneur, Y. 2010. Business Model Generation. New York: Wiley.

Osterwalder, A., Pigneur, Y., \& Tucci, C. 2005. Clarifying Business Models: Origins, Present and Future of the Concept. Communications of the Association for Information Systems, 15: 751-775.

Paul, R., \& Anand, S. 2012. Process Energy Analysis and Optimization in Selective Laser Sintering. Journal of Manufacturing Systems, 31(4): 429-437. http://doi.org/10.1016/j.jmsy.2012.07.004

Paul, R., \& Anand, S. 2015. Optimization of Layered Manufacturing Process for Reducing Form Errors with Minimal Support Structures. Journal of Manufacturing Systems, 36: 231-243. http://doi.org/10.1016/j.jmsy.2014.06.014

Paz, R., Monzon, M. D., Benitez, A. N., \& Gonzalez, B. 2016. New Lightweight Optimisation Method Applied in Parts Made by Selective Laser Sintering and Polyjet Technologies. International Journal of Computer Integrated Manufacturing, 29(4): 462-472. http://doi.org/10.1080/0951192x.2015.1066033

Pisano, P., Pironti, M., \& Rieple, A. 2015. Identify Innovative Business Models: Can Innovative Business Models Enable Players to React to Ongoing or Unpredictable Trends? Entrepreneurship Research Journal, 5(3): 181-199. http://doi.org/10.1515/erj-2014-0032

Popescu, D., Ilie, C., Laptoiu, D., Hadar, A., \& Barbur, R. 2016. WebBased Collaborative Platform for Personalized Orthopaedic Applications. Studies in Informatics and Control, 25(4): 517-526.

Portoles, L., Jorda, O., Jorda, L., Uriondo, A., Esperon-Miguez, M., \& Perinpanayagam, S. 2016. A Qualification Procedure to Manufacture and Repair Aerospace Parts with Electron Beam Melting. Journal of Manufacturing Systems, 41: 65-75. http://doi.org/10.1016/j.jmsy.2016.07.002

Potstada, M., \& Zybura, J. 2014. The Role of Context in Science Fiction Prototyping: The Digital Industrial Revolution. Technological Forecasting and Social Change, 84: 101-114. http://doi.org/10.1016/j.techfore.2013.08.026

Ram, G. D. J., Yang, Y., \& Stucker, B. E. 2006. Effect of Process Parameters on Bond Formation During Ultrasonic Consolidation of Aluminum Alloy 3003. Journal of Manufacturing Systems, 25(3): 221-238. 


\section{Additive Manufacturing and Business Models: Current Knowledge and Missing Perspectives Christina Öberg, Tawfiq Shams, and Nader Asnafi}

Ransikarbum, K., Ha, S., Ma, J., \& Kim, N. 2017. Multi-Objective Optimization Analysis for Part-to-Printer Assignment in a Network of 3D Fused Deposition Modeling. Journal of Manufacturing Systems, 43: 35-46.

http://doi.org/10.1016/j.jmsy.2017.02.012

Rayna, T., \& Striukova, L. 2015. Open Innovation 2.0: Is Co-Creation the Ultimate Challenge? International Journal of Technology Management, 69(1): 38-53.

http://doi.org/10.1504/ijtm.2015.071030

Rayna, T., \& Striukova, L. 2016. From Rapid Prototyping to Home Fabrication: How 3D Printing Is Changing Business Model Innovation. Technological Forecasting and Social Change, 102: 214-224.

http://doi.org/10.1016/j.techfore.2015.07.023

Rayna, T., Striukova, L., \& Darlington, J. 2015. Co-Creation and User Innovation: The Role of Online 3D Printing Platforms. Journal of Engineering and Technology Management, 37: 90-102.

http://doi.org/10.1016/j.jengtecman.2015.07.002

Ren, L., Sparks, T., Ruan, J. Z., \& Liou, F. 2008. Process Planning Strategies for Solid Freeform Fabrication of Metal Parts. Journal of Manufacturing Systems, 27(4): 158-165. http://doi.org/10.1016/j.jmsy.2009.02.002

Rindfleisch, A., O'Hern, M., \& Sachdev, V. 2017. The Digital Revolution, 3D Printing, and Innovation as Data. Journal of Product Innovation Management, 34(5): 681-690. http://doi.org/10.1111/jpim.12402

Roca, J. B., Vaishnav, P., Mendonca, J., \& Morgan, M. G. 2017. Getting Past the Hype about 3D Printing although Additive Manufacturing Techniques Hold Great Promise, Near-Term Expectations for them Are Overoptimistic. MIT Sloan Management Review, 58(3): $57-62$.

Roca, J. B., Vaishnav, P., Morgan, M. G., Mendonca, J., \& Fuchs, E. 2017. When Risks Cannot Be Seen: Regulating Uncertainty in Emerging Technologies. Research Policy, 46(7): 1215-1233. http://doi.org/10.1016/j.respol.2017.05.010

Rogers, H., Baricz, N., \& Pawar, K. S. 2016. 3D Printing Services: Classification, Supply Chain Implications and Research Agenda. International Journal of Physical Distribution \& Logistics Management, 46(10): 886-907.

http://doi.org/10.1108/ijpdlm-07-2016-0210

Ryan, M. J., Eyers, D. R., Potter, A. T., Purvis, L., \& Gosling, J. 2017. 3D Printing the Future: Scenarios for Supply Chains Reviewed. International Journal of Physical Distribution \& Logistics Management, 47(10): 992-1014.

http://doi.org/10.1108/ijpdlm-12-2016-0359

Rylands, B., Bohme, T., Gorkin, R., Fan, J., \& Birtchnell, T. 2016. The Adoption Process and Impact of Additive Manufacturing on Manufacturing Systems. Journal of Manufacturing Technology Management, 27(7): 969-989.

http://doi.org/10.1108/jmtm-12-2015-0117

Salles, A. S., \& Gyi, D. E. 2013. Delivering Personalised Insoles to the High Street Using Additive Manufacturing. International Journal of Computer Integrated Manufacturing, 26(5): 386-400. http://doi.org/10.1080/0951192x.2012.717721

Salvador, M. R., \& de Menendez, A. M. H. 2016. Major Advances in Ophthalmology: Emergence of Bio-Additive Manufacturing. Journal of Intelligence Studies in Business, 6(1): 59-65.
Samford, S., Warrian, P., \& Goracinova, E. 2017. Public and Private Goods in the Development of Additive Manufacturing Capacity. Business and Politics, 19(3): 482-509. http://doi.org/10.1017/bap.2017.4

Sandstrom, C. G. 2016. The Non-Disruptive Emergence of an Ecosystem for 3D Printing - Insights from the Hearing Aid Industry's Transition 1989-2008. Technological Forecasting and Social Change, 102: 160-168. http://doi.org/10.1016/j.techfore.2015.09.006

Sasson, A., \& Johnson, J. C. 2016. The 3D Printing Order: Variability, Supercenters and Supply Chain Reconfigurations. International Journal of Physical Distribution \& Logistics Management, 46(1): 82-94.

http://doi.org/10.1108/ijpdlm-10-2015-0257

Schniederjans, D. G. 2017. Adoption of 3D-Printing Technologies in Manufacturing: A Survey Analysis. International Journal of Production Economics, 183: 287-298.

http://doi.org/10.1016/j.ijpe.2016.11.008

Shams, T., \& Öberg, C. 2017. Disruptive Positions and Roles? The Effect of Additive Manufacturing on Business Networks. Paper presented at the IMP Journal Seminar, October 12-13, 2017, Poznan, Poland.

Sharma, A., Bandari, V., Ito, K., Kohamab, K., Ramji, R. M., \& Himasekhar, H. S. 2017. A New Process for Design and Manufacture of Tailor-Made Functionally Graded Composites Through Friction Stir Additive Manufacturing. Journal of Manufacturing Processes, 26: 122-130.

Simpson, T. W., Williams, C. B., \& Hripko, M. 2017. Preparing Industry for Additive Manufacturing and Its Applications: Summary \& Recommendations from a National Science Foundation Workshop. Additive Manufacturing, 13: 166-178.

Smith, J. M., \& Kerbache, L. 2017. Topological Network Design of Closed Finite Capacity Supply Chain Networks. Journal of Manufacturing Systems, 45: 70-81. http://doi.org/10.1016/j.jmsy.2017.08.001

Stanko, M. A. 2016. Toward a Theory of Remixing in Online Innovation Communities. Information Systems Research, 27(4): 773-791. http://doi.org/10.1287/isre.2016.0650

Steenhuis, H. J., \& Pretorius, L. 2016. Consumer Additive Manufacturing or 3D Printing Adoption: An Exploratory Study. Journal of Manufacturing Technology Management, 27(7): 990-1012.

http://doi.org/10.1108/jmtm-01-2016-0002

Steenhuis, H. J., \& Pretorius, L. 2017. The Additive Manufacturing Innovation: A Range of Implications. Journal of Manufacturing Technology Management, 28(1): 122-143. http://doi.org/10.1108/jmtm-06-2016-0081

Strange, R., \& Zucchella, A. 2017. Industry 4.0, Global Value Chains and International Business. Multinational Business Review, 25(3): $174-184$. http://doi.org/10.1108/mbr-05-2017-0028

Sturm, L. D., Williams, C. B., Camelio, J. A., White, J., \& Parker, R. 2017. Cyber-Physical Vulnerabilities in Additive Manufacturing Systems: A Case Study Attack on the STL File with Human Subjects. Journal of Manufacturing Systems, 44: 154-164. http://doi.org/10.1016/j.jmsy.2017.05.007 


\section{Additive Manufacturing and Business Models: Current Knowledge and Missing Perspectives Christina Öberg, Tawfiq Shams, and Nader Asnafi}

Tatham, P., Loy, J., \& Peretti, U. 2015. Three Dimensional Printing - A Key Tool for the Humanitarian Logistician? Journal of Humanitarian Logistics and Supply Chain Management, 5(2): 188-208.

http://doi.org/10.1108/jhlscm-01-2014-0006

Teece, D. J. 2010. Business Models, Business Strategy and Innovation. Long Range Planning, 43(2-3): 172-194.

Toth, T., Hudak, R., \& Zivcak, J. 2015. Dimensional Verification and Quality Control of Implants Produced By Additive Manufacturing. Quality Innovation Prosperity-Kvalita Inovacia Prosperita, 19(1): 9-21.

http://doi.org/10.12776/qip.v19i1.393

Tranfield, D., Denyer, D., \& Smart, P. 2003. Towards a Methodology for Developing Evidence-Informed Management Knowledge by Means of Systematic Review. British Journal of Management, 14: 207-222.

Trappey, A. J. C., Trappey, C. V., \& Lee, K. L. C. 2017. Tracing the Evolution of Biomedical 3D Printing Technology Using OntologyBased Patent Concept Analysis. Technology Analysis \& Strategic Management, 29(4): 339-352.

http://doi.org/10.1080/09537325.2016.1211267

Tsai, C. Y. 2017. The Impact of Cost Structure on Supply Chain Cash Flow Risk. International Journal of Production Research, 55(22): 6624-6637.

http://doi.org/10.1080/00207543.2017.1330568

Wagner, S. M., \& Walton, R. O. 2016. Additive Manufacturing's Impact and Future in the Aviation Industry. Production Planning \& Control, 27(13): 1124-1130.

http://doi.org/10.1080/09537287.2016.1199824

Walsh, G. S., Przychodzen, J., \& Przychodzen, W. 2017. Supporting the SME Commercialization Process: The Case of 3D Printing Platforms. Small Enterprise Research, 24(3): 257-273. http://doi.org/10.1080/13215906.2017.1396490

Wang, Q. F., Sun, X., Cobb, S., Lawson, G., \& Sharples, S. 2016. 3D Printing System: An Innovation for Small-Scale Manufacturing in Home Settings? Early Adopters of 3D Printing Systems in China. International Journal of Production Research, 54(20): 6017-6032. http://doi.org/10.1080/00207543.2016.1154211

Vanhaverbeke, W., \& Chesbrough, H. 2014. A Classification of Open Innovation and Open Business Models. In H. W. Chesbrough, W. Vanhaverbeke, \& J. West (Eds.), New Frontiers in Open Innovation. Oxford: Oxford University Press.

Weller, C., Kleer, R., \& Piller, F. T. 2015. Economic Implications of 3D Printing: Market Structure Models in Light of Additive Manufacturing Revisited. International Journal of Production Economics, 164: 43-56. http://doi.org/10.1016/j.ijpe.2015.02.020

West, J., \& Kuk, G. 2016. The Complementarity of Openness: How MakerBot Leveraged Thingiverse in 3D Printing. Technological Forecasting and Social Change, 102: 169-181. http://doi.org/10.1016/j.techfore.2015.07.025 von Krogh, G., Spaeth, S., \& Lakhani, K. R. 2003. Community, Joining, and Specialization in Open Source Software Innovation - A Case Study. Research Policy, 32(7): 1217-1241.

Vongbunyong, S., \& Kara, S. 2017. Rapid Generation of Uniform Cellular Structure by Using Prefabricated Unit Cells. International Journal of Computer Integrated Manufacturing, 30(8): 792-804. http://doi.org/10.1080/0951192x.2016.1187303

Wu, Z. Y., Nisar, T., Kapletia, D., \& Prabhakar, G. 2017. Risk Factors for Project Success in the Chinese Construction Industry. Journal of Manufacturing Technology Management, 28(7): 850-866. http://doi.org/10.1108/jmtm-02-2017-0027

Xu, X., Meteyer, S., Perry, N., \& Zhao, Y. F. 2015. Energy Consumption Model of Binder-Jetting Additive Manufacturing Processes. International Journal of Production Research, 53(23): 7005-7015. http://doi.org/10.1080/00207543.2014.937013

Zeleny, M. 2012. High Technology and Barriers to Innovation: From Globalization to Relocalization. International Journal of Information Technology \& Decision Making, 11(2): 441-456. http://doi.org/10.1142/s021962201240010x

Zhang, J. L., Zhang, Z., \& Han, Y. 2017. Research on Manufacturability Optimization of Discrete Products with 3D Printing Involved and Lot-Size Considered. Journal of Manufacturing Systems, 43: $150-159$. http://doi.org/10.1016/j.jmsy.2017.03.002

Zhao, B. T., Lin, Z. W., Fu, J. Z., \& Sun, Y. F. 2017. Generation of TrussStructure Objects with Implicit Representation for 3D-Printing. International Journal of Computer Integrated Manufacturing, 30(8): 871-879. http://doi.org/10.1080/0951192x.2016.1224390

Zhao, X. Y., \& Rosen, D. W. 2017. A Data Mining Approach in RealTime Measurement for Polymer Additive Manufacturing Process with Exposure Controlled Projection Lithography. Journal of Manufacturing Systems, 143: 271-286. http://doi.org/10.1016/j.jmsy.2017.01.005

Zott, C., \& Amit, R. 2010. Business Model Design: An Activity System Perspective. Long Range Planning, 43(2-3): 216-226.

Zott, C., Amit, R., \& Massa, L. 2011. The Business Model: Recent Developments and Future Research. Journal of Management, 37(4): 1019-1042.

Citation: Öberg, C., Shams, T., \& Asnafi, N. 2018. Additive Manufacturing and Business Models: Current Knowledge and Missing Perspectives. Technology Innovation Management Review, 8(6): 15-33. http://doi.org/10.22215/timreview/1162

Keywords: 3D printing, additive manufacturing, business model, literature review 


\section{Additive Manufacturing and Business Models: Current Knowledge and Missing Perspectives Christina Öberg, Tawfiq Shams, and Nader Asnafi}

Appendix 1. Reviewed articles found using the search term "additive manufacturing". Articles are ordered by publication date from newest to oldest. None of the articles included business model as a topic.

\begin{tabular}{|c|c|c|c|}
\hline Article & Journal & Main Theme & Business Model \\
\hline Hartl \& Kort (2017) & $\begin{array}{l}\text { International Journal of Production } \\
\text { Economics }\end{array}$ & $\begin{array}{l}\text { How incumbent firms react to new market entries } \\
\text { of 3D-printing firms }\end{array}$ & Value proposition \\
\hline Ambriz et al. (2017) & Journal of Manufacturing Systems & Material handling related to 3D & Key activities \\
\hline Smith \& Kerbache (2017) & Journal of Manufacturing Systems & $\begin{array}{l}\text { Supply chain network design. Additive } \\
\text { manufacturing (AM) as deconstructing supply } \\
\text { chains }\end{array}$ & Not in focus \\
\hline Samford et al. (2017) & Business and Politics & $\begin{array}{l}\text { High costs of AM leading to difficulties for small } \\
\text { firms to adopt the technology; how can they be } \\
\text { supported }\end{array}$ & Key partners \\
\hline Attaran (2017) & Business Horizons & $\begin{array}{l}\text { AM implementation challenges and opportunities; } \\
\text { changes to production }\end{array}$ & Key activities; offering \\
\hline Roca et al. (2017) & Research Policy & Regulation of emerging technologies & Not in focus \\
\hline Jin et al. (2017) & Journal of Manufacturing Systems & Process planning of AM & Key activities \\
\hline Sturm et al. (2017) & Journal of Manufacturing Systems & Cyberattacks to AM processes & Key resources \\
\hline Le et al. (2017) & Journal of Manufacturing Systems & $\begin{array}{l}\text { The combined use of additive and subtractive } \\
\text { manufacturing }\end{array}$ & Key resources \\
\hline Ransikarbum et al. (2017) & Journal of Manufacturing Systems & $\begin{array}{l}\text { A decision-aiding model to coordinate multiple } \\
\text { printers. Parts. How different printers are needed } \\
\text { and should be coordinated for optimization } \\
\text { (operations). }\end{array}$ & Key resources \\
\hline Giberti et al. (2017) & Journal of Manufacturing Systems & $\begin{array}{l}\text { Original path planning algorithm including AM. } \\
\text { Production processes (operations). }\end{array}$ & Key activities \\
\hline Zhao \& Rosen (2017) & Journal of Manufacturing Systems & $\begin{array}{l}\text { Approach of interferometric curing monitoring } \\
\text { and measuring data mining to intelligently } \\
\text { decipher part height. Parts. Focus on production } \\
\text { processes (operations). }\end{array}$ & Key activities \\
\hline Roca et al. (2017) & MIT Sloan Management Review & $\begin{array}{l}\text { Over-optimism in 3D printing. View on 3D and its } \\
\text { potential influences. }\end{array}$ & Policy/societal level \\
\hline Baumers et al. (2017) & $\begin{array}{l}\text { International Journal of Production } \\
\text { Research }\end{array}$ & $\begin{array}{l}\text { Comparison of costs between AM and traditional } \\
\text { manufacturing, also including changes to } \\
\text { production processes }\end{array}$ & Cost structure \\
\hline Strange \& Zucchella (2017) & Multinational Business Review & $\begin{array}{l}\text { New technologies (web 4.0) affecting location of } \\
\text { firms }\end{array}$ & Not in focus \\
\hline Jin et al. (2017) & $\begin{array}{l}\text { International Journal of Computer } \\
\text { Integrated Manufacturing }\end{array}$ & $\begin{array}{l}\text { Extrusion-based layered deposition as an AM } \\
\text { technology }\end{array}$ & Key resources \\
\hline $\begin{array}{l}\text { Vongbunyong \& Kara } \\
(2017)\end{array}$ & $\begin{array}{l}\text { International Journal of Computer } \\
\text { Integrated Manufacturing }\end{array}$ & $\begin{array}{l}\text { Cellular structure enabled through AM. Focus on } \\
\text { the manufacturing. }\end{array}$ & Key resources \\
\hline Niaki \& Nonino (2017) & $\begin{array}{l}\text { Journal of Manufacturing Technology } \\
\text { Management }\end{array}$ & Impact of $A M$ on business performance & Value proposition \\
\hline Aboutaleb et al. (2017) & IIE Transactions & $\begin{array}{l}\text { Optimizing processes from a cost and time } \\
\text { perspective. Parts. Manufacturing (operations). }\end{array}$ & Key activities \\
\hline Li et al. (2017) & $\begin{array}{l}\text { International Journal of Production } \\
\text { Research }\end{array}$ & $\begin{array}{l}\text { The impact of AM on spare parts supply chain. } \\
\text { Simulations. Parts. Supply chain. }\end{array}$ & Key activities \\
\hline Popescu et al. (2016) & Studies in Informatics and Control & $\begin{array}{l}\text { Communities/platforms in orthopedic } \\
\text { applications }\end{array}$ & Not in focus \\
\hline Portoles et al. (2016) & Journal of Manufacturing Systems & $\begin{array}{l}\text { Quality assurance in AM for aero industry. Parts, } \\
\text { metallic. Manufacturing. }\end{array}$ & Key activities \\
\hline Chen \& Xiao (2016) & Systems \& Control Letters & Disturbances in production & Not in focus \\
\hline
\end{tabular}




\section{Additive Manufacturing and Business Models: Current Knowledge and Missing \\ Perspectives Christina Öberg, Tawfiq Shams, and Nader Asnafi}

Appendix 1. (continued) Reviewed articles found using the search term "additive manufacturing". Articles are ordered by publication date from newest to oldest. None of the articles included business model as a topic.

\begin{tabular}{|c|c|c|c|}
\hline Article & Journal & Main Theme & Business Model \\
\hline Manogharan et al. (2016) & $\begin{array}{l}\text { International Journal of Computer } \\
\text { Integrated Manufacturing }\end{array}$ & $\begin{array}{l}\text { Economic models (cost side) of additive and } \\
\text { subtractive methods. Manufacturing and cost- } \\
\text { side. }\end{array}$ & Cost structure \\
\hline Paz et al. (2016) & $\begin{array}{l}\text { International Journal of Computer } \\
\text { Integrated Manufacturing }\end{array}$ & $\begin{array}{l}\text { Optimized design of parts (e.g., different } \\
\text { structures of material). Parts. Manufacturing. }\end{array}$ & Key activities \\
\hline Featherston et al. (2016) & Technovation & New technologies & Not in focus \\
\hline Wagner \& Walton (2016) & Production Planning \& Control & $\begin{array}{l}\text { The current and future states of } A M \text { in the aviation } \\
\text { industry. Supply chain. Parts. }\end{array}$ & Key resources \\
\hline Bastani et al. (2016) & IIE Transactions & $\begin{array}{l}\text { AM as an empirical example to test online sparse } \\
\text { estimation-based classification. }\end{array}$ & Not in focus \\
\hline Caputo et al. (2016) & $\begin{array}{l}\text { Business Process Management } \\
\text { Journal }\end{array}$ & Internet of Things framework tested on AM. & Not in focus \\
\hline Xu et al. (2015) & $\begin{array}{l}\text { International Journal of Production } \\
\text { Research }\end{array}$ & $\begin{array}{l}\text { A method to build an energy consumption model } \\
\text { for printing stage of binder-jetting processes }\end{array}$ & Key activities \\
\hline Gartner et al. (2015) & $\begin{array}{l}\text { Creativity and Innovation } \\
\text { Management }\end{array}$ & The need for policies about $\mathrm{AM}$ & Policy/societal level \\
\hline Kim et al. (2015) & $\begin{array}{l}\text { Concurrent Engineering-Research } \\
\text { and Applications }\end{array}$ & $\begin{array}{l}\text { AM process example to illustrate processes in } \\
\text { smart manufacturing environments }\end{array}$ & Key activities \\
\hline Mohr \& Khan (2015) & $\begin{array}{l}\text { Technology Innovation Management } \\
\text { Review }\end{array}$ & $\begin{array}{l}\text { The areas of the supply chain most likely to be } \\
\text { disrupted by 3D printing technology }\end{array}$ & Key activities \\
\hline Ali \& Rehman (2015) & Journal of Manufacturing Systems & Novel manufacturing methods in medicine & Key activities \\
\hline Gardan \& Schneider (2015) & Journal of Manufacturing Systems & $\begin{array}{l}\text { How what is manufactured is allowed to change } \\
\text { (complex geometrics) by means of AM }\end{array}$ & Key resources \\
\hline Paul \& Anand (2015) & Journal of Manufacturing Systems & Analysis of form errors & Key resources \\
\hline Eyers \& Potter (2015) & $\begin{array}{l}\text { Journal of Manufacturing Technology } \\
\text { Management }\end{array}$ & $\begin{array}{l}\text { The use of e-channels for files between designer } \\
\text { and manufacturer in AM }\end{array}$ & Key resources \\
\hline Appleyard (2015) & Business Horizons & $\begin{array}{l}\text { The development of the music industry (piracy) as } \\
\text { example to understand AM as a production } \\
\text { process owned by consumers }\end{array}$ & Customer relationships \\
\hline Toth et al. (2015) & Quality Innovation Prosperity & $\begin{array}{l}\text { The use of } 3 \mathrm{D} \text { for customized implant } \\
\text { manufacturing }\end{array}$ & Key resources \\
\hline Liu et al. (2014) & Production Planning \& Control & $\begin{array}{l}\text { The impact of } A M \text { in the aircraft spare parts supply } \\
\text { chain. Scenarios including distributed and } \\
\text { centralized supply chains. }\end{array}$ & Key activities \\
\hline Christopher \& Ryals (2014) & Journal of Business Logistics & $\begin{array}{l}\text { From supply chain to demand chain. } \mathrm{AM} \text { as one of } \\
\text { the clues for this. }\end{array}$ & Customer relationships \\
\hline Mellor et al. (2014) & $\begin{array}{l}\text { International Journal of Production } \\
\text { Economics }\end{array}$ & Implementation framework for $\mathrm{AM}$ & Key activities \\
\hline Salles \& Gyi (2013) & $\begin{array}{l}\text { International Journal of Computer } \\
\text { Integrated Manufacturing }\end{array}$ & $\begin{array}{l}\text { The production of personalized footwear through } \\
\text { AM }\end{array}$ & Value proposition \\
\hline Paul \& Anand (2012) & Journal of Manufacturing Systems & Energy calculations for laser sintering & Key resources \\
\hline Berman (2012) & Business Horizons & $\begin{array}{l}3 \mathrm{D} \text { as a revolution. Current practices mostly } \\
\text { prototyping though }\end{array}$ & Value proposition \\
\hline Ren et al. (2008) & Journal of Manufacturing Systems & $\begin{array}{l}\text { Process planning of AM of metals testing various } \\
\text { techniques }\end{array}$ & Key activities \\
\hline Bingham et al. (2007) & $\begin{array}{l}\text { International Journal of Computer } \\
\text { Integrated Manufacturing }\end{array}$ & $\begin{array}{l}\text { Rapid manufacturing in textile through AM. } \\
\text { Technological focus. }\end{array}$ & Key resources \\
\hline Ram et al. (2006) & Journal of Manufacturing Systems & $\begin{array}{l}\text { Layer-based 3D printing in metals. Technology in } \\
\text { focus. }\end{array}$ & Key activities \\
\hline
\end{tabular}




\section{Additive Manufacturing and Business Models: Current Knowledge and Missing \\ Perspectives Christina Öberg, Tawfiq Shams, and Nader Asnafi}

Appendix 2. Reviewed articles found using the search term "3D printing". Articles are ordered by publication date from newest to oldest. Articles in bold include business model as a topic.

\begin{tabular}{|c|c|c|c|}
\hline Article & Journal & Main Theme & Business Model \\
\hline Flath et al. (2017) & $\begin{array}{l}\text { Journal of Information } \\
\text { Technology }\end{array}$ & Platforms for 3D design & Key partners \\
\hline Rindfleisch et al. (2017) & $\begin{array}{l}\text { Journal of Product Innovation } \\
\text { Management }\end{array}$ & Innovation as data, 3D as example & Not in focus \\
\hline Dotsika \& Watkins (2017) & $\begin{array}{l}\text { Technological Forecasting and } \\
\text { Social Change }\end{array}$ & $\begin{array}{l}\text { 3D as one of several disruptive technologies. } \\
\text { Focus on methods to discover disruptive } \\
\text { technologies. }\end{array}$ & Not in focus \\
\hline Hartmann \& Vanpoucke (2017) & $\begin{array}{l}\text { Journal of Organizational and } \\
\text { End User Computing }\end{array}$ & $\begin{array}{l}\text { Customer acceptance with } 3 \mathrm{D} \text { as an example } \\
\text { (intention to use) }\end{array}$ & Value proposition \\
\hline Zhang et al. (2017) & $\begin{array}{l}\text { Journal of Manufacturing } \\
\text { Systems }\end{array}$ & $\begin{array}{l}\text { Manufacturability optimization in processes } \\
\text { including 3D and traditional manufacturing. } \\
\text { Production processes (operations). }\end{array}$ & Key activities \\
\hline Kyriakou et al. (2017) & MIS Quarterly & $\begin{array}{l}\text { The reuse of 3D models. Customization and } \\
\text { supply-side in communities. }\end{array}$ & $\begin{array}{l}\text { Key partners; customer } \\
\text { relationships }\end{array}$ \\
\hline Walsh et al. (2017) & Small Enterprise Research & $\begin{array}{l}\text { How 3D platforms support small firms in their } \\
\text { innovation and commercialization processes }\end{array}$ & Key resources \\
\hline Tsai $(2017)$ & $\begin{array}{l}\text { International Journal of } \\
\text { Production Research }\end{array}$ & $\begin{array}{l}\text { The impact of cost structure on cash flow risk; } \\
\text { AM as one example }\end{array}$ & Cost structure \\
\hline Wu et al. (2017) & $\begin{array}{l}\text { Journal of Manufacturing } \\
\text { Technology Management }\end{array}$ & Risks in projects & Not in focus \\
\hline Zhao et al. (2017) & $\begin{array}{l}\text { International Journal of } \\
\text { Computer Integrated } \\
\text { Manufacturing }\end{array}$ & Truss structures enabled through 3D printing & Key resources \\
\hline Bai et al. (2017) & $\begin{array}{l}\text { Journal of Manufacturing } \\
\text { Technology Management }\end{array}$ & $\begin{array}{l}\text { Comparative advantage of 3D printing among } \\
\text { countries }\end{array}$ & Value proposition \\
\hline Long et al. (2017) & $\begin{array}{l}\text { International Journal of } \\
\text { Production Research }\end{array}$ & The impact of 3D on Chinese manufacturing & Key activities \\
\hline Schniederjans (2017) & $\begin{array}{l}\text { International Journal of } \\
\text { Production Economics }\end{array}$ & $\begin{array}{l}\text { Adoption of 3D technology among top } \\
\text { managers. }\end{array}$ & Key activities \\
\hline Stanko (2016) & Information Systems Research & Online communities & Not in focus \\
\hline Kannattukunnel (2016) & $\begin{array}{l}\text { International Journal of } \\
\text { Innovation and Technology } \\
\text { Management }\end{array}$ & $\begin{array}{l}\text { Patents and investments in 3D. } \\
\text { Technology/manufacturing. }\end{array}$ & Key activities \\
\hline Laplume et al. (2016a) & $\begin{array}{l}\text { International Journal of } \\
\text { Advanced Manufacturing } \\
\text { Technology }\end{array}$ & $\begin{array}{l}\text { The use of 3D printing for small manufacturing } \\
\text { firms in their offerings }\end{array}$ & Value proposition \\
\hline Kothman \& Faber (2016) & $\begin{array}{l}\text { Journal of Manufacturing } \\
\text { Technology Management }\end{array}$ & $\begin{array}{l}\text { Impact of AM on performance: efficient } \\
\text { manufacturing and changed supply chain } \\
\text { structure }\end{array}$ & Key activities \\
\hline Maric et al. (2016) & $\begin{array}{l}\text { Journal of Innovation Economics } \\
\text { \& Management }\end{array}$ & Frugal innovation & Value proposition \\
\hline
\end{tabular}




\section{Additive Manufacturing and Business Models: Current Knowledge and Missing \\ Perspectives Christina Öberg, Tawfiq Shams, and Nader Asnafi}

Appendix 2. (continued) Reviewed articles found using the search term "3D printing”. Articles are ordered by publication date from newest to oldest. Articles in bold include business model as a topic.

\begin{tabular}{|c|c|c|c|}
\hline Article & Journal & Main Theme & Business Model \\
\hline Elango et al. (2016) & $\begin{array}{l}\text { International Journal of } \\
\text { Production Research }\end{array}$ & $\begin{array}{l}\text { Technology of 3D printers. Technology } \\
\text { (manufacturing). }\end{array}$ & Key resources \\
\hline Wang et al. (2016) & $\begin{array}{l}\text { International Journal of } \\
\text { Production Research }\end{array}$ & $\begin{array}{l}\text { Chinese consumers' adaption of } 3 \mathrm{D} \text { for home- } \\
\text { based manufacturing. }\end{array}$ & Key resources \\
\hline Sasson \& Johnson (2016) & $\begin{array}{l}\text { International Journal of Physical } \\
\text { Distribution \& Logistics } \\
\text { Management }\end{array}$ & $\begin{array}{l}\text { Direct digital manufacturing coexisting with } \\
\text { traditional manufacturing methods. (Supply } \\
\text { chain changes). }\end{array}$ & Key activities \\
\hline West \& Kuk (2016) & $\begin{array}{l}\text { Technological Forecasting and } \\
\text { Social Change }\end{array}$ & $\begin{array}{l}\text { Openness in 3D printing. Manufacturing } \\
\text { (community-based, that is, its organizing) }\end{array}$ & Key partners \\
\hline Rayna \& Striukova (2016) & $\begin{array}{l}\text { Technological Forecasting and } \\
\text { Social Change }\end{array}$ & 3D printing affecting business models & Value proposition \\
\hline Hull (2015) & $\begin{array}{l}\text { Research-Technology } \\
\text { Management }\end{array}$ & Development, descriptive & Key resources \\
\hline Han \& Sohn (2015) & Journal of Technology Transfer & Patents. 3D as empirics. & Not in focus \\
\hline Pisano et al. (2015) & $\begin{array}{l}\text { Entrepreneurship Research } \\
\text { Journal }\end{array}$ & $\begin{array}{l}\text { Business models as a means to better react to } \\
\text { new trends. 3D as one example. }\end{array}$ & Key activities \\
\hline Rayna et al. (2015) & $\begin{array}{l}\text { Journal of Engineering and } \\
\text { Technology Management }\end{array}$ & Online 3D printing and its effect for co-creation & Customer relationships \\
\hline Huang et al. (2015) & IIE Transactions & Shape shrinkage in manufacturing with $3 \mathrm{D}$ & Key resources \\
\hline Rayna \& Striukova (2015) & $\begin{array}{l}\text { International Journal of } \\
\text { Technology Management }\end{array}$ & Challenges of co-creation. 3D as one example. & Key partners \\
\hline Mavri (2015) & $\begin{array}{l}\text { Knowledge and Process } \\
\text { Management }\end{array}$ & Change in production chain due to $\mathrm{AM}$ & Key activities \\
\hline Potstada \& Zybura (2014) & $\begin{array}{l}\text { Technological Forecasting and } \\
\text { Social Change }\end{array}$ & Home printing for consumers & Key activities \\
\hline Fawcett \& Waller (2014) & Journal of Business Logistics & Adaptation and proactiveness & Key activities \\
\hline Zeleny (2012) & $\begin{array}{l}\text { International Journal of } \\
\text { Information Technology \& } \\
\text { Decision Making }\end{array}$ & $\begin{array}{l}\text { Barriers to innovation. } 3 \text { D mentioned as one } \\
\text { technology affecting innovation and changing } \\
\text { customers' role. }\end{array}$ & Not in focus \\
\hline
\end{tabular}




\section{Additive Manufacturing and Business Models: Current Knowledge and Missing \\ Perspectives Christina Öberg, Tawfiq Shams, and Nader Asnafi}

Appendix 3. Reviewed articles found using the search terms "additive manufacturing” AND "3D printing”. Articles are ordered by publication date from newest to oldest. Articles in bold include business model as a topic.

\begin{tabular}{|c|c|c|c|}
\hline Article & Journal & Main Theme & Business Model \\
\hline Ben-Ner \& Siemsen (2017) & California Management Review & $\begin{array}{l}\text { Changes to production: from global to local; } \\
\text { from mega to mini; from long to short supply } \\
\text { chains }\end{array}$ & Key activities \\
\hline Birtchnell et al. (2017) & $\begin{array}{l}\text { Technological Forecasting and } \\
\text { Social Change }\end{array}$ & $\begin{array}{l}\text { The role of universities in the development of } 3 \mathrm{D} \\
\text { printing knowledge }\end{array}$ & Key partners \\
\hline Li et al. (2017) & $\begin{array}{l}\text { Computers \& Operations } \\
\text { Research }\end{array}$ & $\begin{array}{l}\text { Cost functions of AM. Very different cost } \\
\text { structures to traditional manufacturing. }\end{array}$ & Key resources \\
\hline Jiang et al. (2017) & $\begin{array}{l}\text { Technological Forecasting and } \\
\text { Social Change }\end{array}$ & $\begin{array}{l}\text { Scenarios on future development (2030) through } \\
\text { Delphi methods }\end{array}$ & Policy/societal level \\
\hline Trappey et al. (2017) & $\begin{array}{l}\text { Technology Analysis \& Strategic } \\
\text { Management }\end{array}$ & $\begin{array}{l}\text { Patent analysis approach to explore biomedical } \\
\text { 3D printing technology trends. Technology. }\end{array}$ & Key resources \\
\hline Despeisse et al. (2017) & $\begin{array}{l}\text { Technological Forecasting and } \\
\text { Social Change }\end{array}$ & $\begin{array}{l}\text { Whether or not 3D will lead to sustainability, } \\
\text { and how it need to function to do so. How } 3 \mathrm{D} \\
\text { affects - positively and negatively - the } \\
\text { development of a circular economy. }\end{array}$ & Policy/societal level \\
\hline Durach et al. (2017) & $\begin{array}{l}\text { International Journal of Physical } \\
\text { Distribution \& Logistics } \\
\text { Management }\end{array}$ & $\begin{array}{l}\text { AM processes, their barriers and impact on } \\
\text { supply chains }\end{array}$ & Key activities (supply chain) \\
\hline Dwivedi et al. (2017) & $\begin{array}{l}\text { International Journal of Physical } \\
\text { Distribution \& Logistics } \\
\text { Management }\end{array}$ & $\begin{array}{l}\text { Barriers to AM in Indian car industry; } \\
\text { technological skills and governmental support } \\
\text { as main issues }\end{array}$ & Key resources \\
\hline Ryan et al. (2017) & $\begin{array}{l}\text { International Journal of Physical } \\
\text { Distribution \& Logistics } \\
\text { Management }\end{array}$ & Scenarios for 3D printing. Supply chain. & Key activities \\
\hline Achillas et al. (2017) & $\begin{array}{l}\text { International Journal of } \\
\text { Production Research }\end{array}$ & $\begin{array}{l}\text { Different AM technologies are compared in } \\
\text { terms of lead time and total production cost } \\
\text { with injection molding }\end{array}$ & Key activities \\
\hline Gibson (2017) & $\begin{array}{l}\text { Journal of Manufacturing } \\
\text { Technology Management }\end{array}$ & $\begin{array}{l}\text { State of the art in 3D printing related to } \\
\text { business. Changed applications over time. }\end{array}$ & Value proposition \\
\hline Holzmann et al. (2017) & $\begin{array}{l}\text { Journal of Manufacturing } \\
\text { Technology Management }\end{array}$ & $\begin{array}{l}\text { User entrepreneur business models in 3D } \\
\text { printing }\end{array}$ & Value proposition \\
\hline Deradjat \& Minshall (2017) & $\begin{array}{l}\text { Journal of Manufacturing } \\
\text { Technology Management }\end{array}$ & $\begin{array}{l}\text { Dental sector; implementation of } 3 \mathrm{D} \text { for mass } \\
\text { customization. Focus on technology. }\end{array}$ & Key resources \\
\hline Steenhuis \& Pretorius (2017) & $\begin{array}{l}\text { Journal of Manufacturing } \\
\text { Technology Management }\end{array}$ & $\begin{array}{l}\text { AM innovations. Focus on issue of IP among } \\
\text { others. }\end{array}$ & Key resources \\
\hline Laplume et al. (2016b) & $\begin{array}{l}\text { Journal of International Business } \\
\text { Studies }\end{array}$ & $\begin{array}{l}\text { Ideas (about the future) and how 3D may impact } \\
\text { global supply chains. Increased geographically } \\
\text { dispersion and production closer to the end } \\
\text { users (localization). Changes to supply chain. } \\
\text { Future oriented. }\end{array}$ & Key activities \\
\hline Holmstrom et al. (2016) & $\begin{array}{l}\text { Operations Management } \\
\text { Research }\end{array}$ & $\begin{array}{l}\text { Discussion of current over-optimism for } 3 D \text { and } \\
\text { how it in the future may change supply chains, } \\
\text { etc., but not yet indicates the major shift and } \\
\text { advantage to current production methods. } \\
\text { Supply chain. }\end{array}$ & Key activities \\
\hline Gardan (2016) & $\begin{array}{l}\text { International Journal of } \\
\text { Production Research }\end{array}$ & $\begin{array}{l}\text { Review of the different AM technologies and the } \\
\text { new trends. Focus on technology and } \\
\text { manufacturing. Technology/manufacturing } \\
\text { process }\end{array}$ & Key activities \\
\hline Meisel et al. (2016) & $\begin{array}{l}\text { Journal of Manufacturing } \\
\text { Technology Management }\end{array}$ & Decision support for AM; focus on resources & Key resources \\
\hline
\end{tabular}




\section{Additive Manufacturing and Business Models: Current Knowledge and Missing \\ Perspectives Christina Öberg, Tawfiq Shams, and Nader Asnafi}

Appendix 3. (continued) Reviewed articles found using the search terms "additive manufacturing" AND "3D printing". Articles are ordered by publication date from newest to oldest. Articles in bold include business model as a topic.

\begin{tabular}{|c|c|c|c|}
\hline Article & Journal & Main Theme & Business Model \\
\hline Knofius et al. (2016) & $\begin{array}{l}\text { Journal of Manufacturing } \\
\text { Technology Management }\end{array}$ & Spare parts through AM in logistics & Key resources \\
\hline Oettmeier \& Hofmann (2016) & $\begin{array}{l}\text { Journal of Manufacturing } \\
\text { Technology Management }\end{array}$ & $\begin{array}{l}\text { Impact of AM on supply chain components and } \\
\text { processes. Hearing industry. }\end{array}$ & Key activities \\
\hline Rylands et al. (2016) & $\begin{array}{l}\text { Journal of Manufacturing } \\
\text { Technology Management }\end{array}$ & $\begin{array}{l}\text { Adaptation of } A M \text { in manufacturing and its } \\
\text { business impact }\end{array}$ & Value proposition \\
\hline Steenhuis \& Pretorius (2016) & $\begin{array}{l}\text { Journal of Manufacturing } \\
\text { Technology Management }\end{array}$ & $\begin{array}{l}\text { Consumer AM impact on future manufacturing } \\
\text { industry }\end{array}$ & Key resources \\
\hline Rogers et al. (2016) & $\begin{array}{l}\text { International Journal of Physical } \\
\text { Distribution \& Logistics } \\
\text { Management }\end{array}$ & $\begin{array}{l}\text { 3D services and their impact on supply chains. } \\
\text { Literature review and research agenda. Services } \\
\text { (external parties' provision). Supply chain. }\end{array}$ & Key activities \\
\hline Mortara \& Parisot (2016) & $\begin{array}{l}\text { International Journal of } \\
\text { Production Research }\end{array}$ & $\begin{array}{l}\text { AM as one of several production techniques at } \\
\text { fab-spaces (not key focus). Manufacturing. } \\
\text { Organizing of manufacturing. }\end{array}$ & Key activities \\
\hline Salvador \& de Menendez (2016) & $\begin{array}{l}\text { Journal of Intelligence Studies in } \\
\text { Business, }\end{array}$ & $\begin{array}{l}\text { The potential effect of bio-additive } \\
\text { manufacturing on healthcare }\end{array}$ & Key activities \\
\hline Sandstrom (2016) & $\begin{array}{l}\text { Technological Forecasting and } \\
\text { Social Change }\end{array}$ & $\begin{array}{l}\text { How AM has been adopted for manufacturing } \\
\text { and its potential impact competition in different } \\
\text { industries. Hearing aid case study. Technology } \\
\text { and new manufacturing possibilities. }\end{array}$ & Key resources \\
\hline Baumers et al. (2016) & $\begin{array}{l}\text { Technological Forecasting and } \\
\text { Social Change }\end{array}$ & $\begin{array}{l}\text { Cost performance using two different } \\
\text { techniques }\end{array}$ & Cost structure \\
\hline Bogers et al. (2016) & $\begin{array}{l}\text { Technological Forecasting and } \\
\text { Social Change }\end{array}$ & $\begin{array}{l}\text { The implications of AM on production systems } \\
\text { in new business models. Focus on consumer } \\
\text { goods and open business models implying a } \\
\text { consumer-centric logic and changes to supply } \\
\text { chains. }\end{array}$ & Key activities \\
\hline Hoover \& Lee (2015) & $\begin{array}{l}\text { Research-Technology } \\
\text { Management }\end{array}$ & $\begin{array}{l}\text { 3D as one force of change in the current } \\
\text { business landscape (in parallel with, e.g., } \\
\text { sharing) }\end{array}$ & Key activities \\
\hline Achillas et al. (2015) & $\begin{array}{l}\text { Journal of Manufacturing } \\
\text { Systems }\end{array}$ & $\begin{array}{l}\text { A decision-making framework for selecting an } \\
\text { effective portfolio of production strategies, } \\
\text { including alternative additive and traditional } \\
\text { manufacturing technologies. AM effective for } \\
\text { small series and high customization (increased } \\
\text { supply chain responsiveness). Injection molds } \\
\text { to traditional manufacturing also in larger series. }\end{array}$ & Key activities \\
\hline Weller et al. (2015) & $\begin{array}{l}\text { International Journal of } \\
\text { Production Economics }\end{array}$ & $\begin{array}{l}\text { The impact of } A M \text { on firm and industry level } \\
\text { from an operational management perspective. } \\
\text { In monopoly situation, firms may increase their } \\
\text { revenues, while in competitive markets, AM } \\
\text { lowers entrance barriers }\end{array}$ & Revenue stream \\
\hline Kietzmann et al. (2015) & Business Horizons & The impact of $A M$ on firms and consumers & Value proposition \\
\hline Tatham et al. (2015) & $\begin{array}{l}\text { Journal of Humanitarian } \\
\text { Logistics and Supply Chain } \\
\text { Management }\end{array}$ & $\begin{array}{l}\text { The use of 3D in disaster and development } \\
\text { activities }\end{array}$ & Key activities \\
\hline Kurfess \& Cass (2014) & $\begin{array}{l}\text { Research-Technology } \\
\text { Management }\end{array}$ & Intellectual property changes as a result of AM & Key resources \\
\hline Kurman (2014) & $\begin{array}{l}3 D \text { Printing and Additive } \\
\text { Manufacturing }\end{array}$ & Intellectual property as inefficient in $A M$ & Key resources \\
\hline
\end{tabular}




\section{Academic Affiliations and Funding Acknowledgements}

Canadà
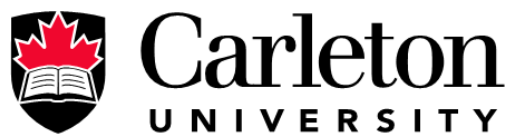

U N I V E R S I T Y

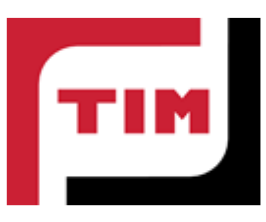

The Federal Economic Development Agency for Southern Ontario (FedDev Ontario; feddevontario.gc.ca) is part of the Innovation, Science and Economic Development portfolio and one of six regional development agencies, each of which helps to address key economic challenges by providing regionallytailored programs, services, knowledge and expertise.

- The TIM Review receives partial funding from FedDev Ontario's Investing in Regional Diversification initiative.

Technology Innovation Management (TIM; timprogram.ca) is an international master's level program at Carleton University in Ottawa, Canada. It leads to a Master of Applied Science (M.A.Sc.) degree, a Master of Engineering (M.Eng.) degree, or a Master of Entrepreneurship (M.Ent.) degree. The objective of this program is to train aspiring entrepreneurs on creating wealth at the early stages of company or opportunity lifecycles.

- The TIM Review is published in association with and receives partial funding from the TIM program. 